\title{
Surfactant in children with malignancies, immunosuppression, fever and pulmonary infiltrates
}

\author{
M. Griese*, M. Neumann*, T. von Bredow*, R. Schmidt", F. Ratjen
}

Surfactant in children with malignancies, immunosuppression, fever and pulmonary infiltrates. M. Griese, M. Neumann, T. von Bredow, R. Schmidt, F. Ratjen. (C)ERS Journals Ltd 2002.

ABSTRACT: In children with malignancies and immunosuppression, significant morbidity and mortality result from respiratory complications. The aim of the present study was to investigate whether or not this is associated with altered surfactant components or functions.

Bronchoalveolar lavage fluid from 24 children with malignancies, immunosuppression, pulmonary infiltrates and fever unresponsive to empirical antibiotic treatment were compared to that from 24 healthy children. Levels of surfactant protein (SP) A and D and their binding capacity for Pseudomonas aeruginosa, as well as levels of SP-B and SP-C, were assessed by enzyme-linked immunosorbent assay. The large and small surfactant aggregate forms were separated and the biophysical activity of large surfactant aggregates was determined using a pulsating bubble surfactometer.

Compared to healthy controls, SP-A levels were increased four-fold, the increase being most pronounced in those children with pathogens recovered from their bronchoalveolar lavage fluid. In children with malignancies, levels of SP-C were increased two-fold and of small surfactant aggregates five-fold. No differences were observed in levels of SP-B or SP-D, binding capacity of SP-A or SP-D or the surface activity of large surfactant aggregates.

The increased levels of surfactant protein $A$, particularly in children with recovered microorganisms, and unchanged binding capacity of surfactant protein A are consistent with upregulated local host defence mechanisms. Increased surfactant protein $A$ and $C$ may also be responsible for the conserved biophysical activity of surfactant in children with malignancies, immunosuppression, pulmonary infiltrates and fever.

Eur Respir J 2002; 20: 1284-1291.
*Children's Hospital, Ludwig Maximilians University, Munich, " Dept of Internal Medicine, University of Giessen, Giessen, and 'Children's Hospital, University of Essen, Essen, Germany.

Correspondence: M. Griese, Kinderklinik and Kinderpoliklinik im Dr von Haunerschen, Kinderspital, LudwigMaximilians University, Pettenkoferstr. 8a, D-80336 Munich, Germany.

Fax: 498951603477

E-mail: griese@pk-i.med.uni-muenchen.de

Keywords: Bronchoalveolar lavage neutropaenic

phospholipids

small and large surfactant aggregates

surface tension

surfactant protein

Received: January 162001

Accepted after revision: June 92002
The treatment of malignant diseases is often complicated by lower airway infections during immunosuppression. In children, initial empirical treatment with broad spectrum antibiotics is often successful. If, however, the fever persists and lung infiltrates increase, diagnostic bronchoalveolar lavage (BAL) can be used to recover pathogenic organisms and assist treatment [1].

The factors determining the severity of the infections are not completely understood, but include host factors, such as the degree of immunosuppression, as well as virulence factors, such as exposure to specific microorganisms. Additionally, the concentration and regulation of local innate immune factors in the epithelial lining fluid of the lungs may predispose to or determine the course in a given patient. Pulmonary surfactant protein (SP) A and SP-D appear to be pivotal in the innate immune responses to various microorganisms. This was established by in vitro experiments [2] and in vivo studies in knockout mice. Mice targeted for deletion of SP-A show increased susceptibility to and mortality from Streptococcus pyogenes, Pseudomonas aeruginosa, respiratory syncytial virus and other viruses [3, 4]. Recently,
SP-D-deficient mice were shown to have increased numbers of pulmonary inflammatory cells and a higher percentage of neutrophils after challenge with respiratory syncytial virus or lipopolysaccharide [5, 6]. In addition to the immunoregulatory functions of these surfactant components, SP-A and the hydrophobic SP-B and SP-C have important biophysical functions in the lungs [7]. The patency and stability of the small airways and alveoli during expiration and inhibition of oedema formation in the lungs all principally depend on surfactant containing sufficient functional SP-A, SP-B and SP-C.

The concentrations and regulation of these SPs are unknown in children who develop severe respiratory complications during immunosuppressive treatment of neoplasms. Altered biophysical performance of surfactant may contribute to atelectasis and inhibit clearance of secretions and debris from the airspaces, and altered levels or properties of SP-A and SP-D may impair host defence mechanisms and thus influence the clinical course of pulmonary infections. During pneumonia, the level of SP-A is decreased [8, 9] and minimal surface tension increased [9]; no data on SP-C have been reported [10]. In addition, the content 
of the small (SA) and large (LA) surfactant aggregates is changed during pneumonia and nosocomial infection in neonates [11] and adults [9]. The LA fraction is the more surface active and is believed to be mainly responsible for the surface active properties of surfactant [12].

The goal of the present study was to assess the levels of the four SPs, and LA and SA, and the surface activity of surfactant recovered by BAL from children with immunosuppression during treatment for malignancies, fever unresponsive to therapy and pulmonary infiltrates and compare these results with those obtained in normal children. The hypothesis was that altered concentrations of these key components of pulmonary surfactant were associated with the presence or absence of specific pathogens, radiological infiltrates or outcome.

\section{Patients and methods}

\section{Control children}

Twenty-four healthy children (median age 10.2 yrs (range 4.5-15.3 yrs), 14 male) with no cardiopulmonary disease and no history of either chronic respiratory symptoms or recent upper or lower respiratory tract infection were studied. All children were undergoing elective surgery for nonpulmonary illnesses, such as minor abnormalities of the urogenital tract (hypospadias and vesiculouretheral reflux; $n=11$ ), tonsillectomy $(\mathrm{n}=5)$, adenectomy $(\mathrm{n}=6)$ and lateral neck cysts $(n=2)$. BAL was performed using a flexible bronchoscope (Pentax $\AA$, Hamburg, Germany; outer diameter of $3.5 \mathrm{~mm}$ in children aged $<10$ yrs and $4.9 \mathrm{~mm}$ in older children) during general anaesthesia (nitrous oxide, oxygen and halothane $1-5 \%$ ) and tracheal intubation. The study was approved by the institutional review board and informed consent was obtained from the parents before the study.

\section{Children with malignancies and immunosuppression}

Bronchoscopy was performed via a flexible endoscope following topical anaesthesia, achieved by inhalation of nebulised lidocaine $4 \%$ prior to bronchoscopy and instillation of $2 \%$ lidocaine as needed when the bronchoscope was in the airways. Lidocaine, tested over a final concentration range of $0.00001-0.1 \%$, had no effect on the assay systems used. Patients were sedated with $0.3 \mathrm{mg} \cdot \mathrm{kg}$ body weight ${ }^{-1}$ midazolam. BAL was carried out prospectively in 24 consecutive children with various malignancies who presented with diffuse infiltrates on radiography for $>48 \mathrm{~h}$ or who did not respond to primary empirical antibiotic therapy. Details of the patients and their courses are presented in table 1 . The median age of the children at lavage was 8.1 yrs (range 2.0-16.5 yrs). The study was approved by the institutional review board and informed consent was obtained from the parents before the study.

\section{Bronchoalveolar lavage and processing of lavage fluid}

The bronchoscope was wedged in the middle lobe in all control children and children with malignancies and diffuse infiltrates. In children with localised infiltrates, the lobes with the most pronounced radiological changes were lavaged. Saline $0.9 \%$ $\left(3 \mathrm{~mL} \cdot \mathrm{kg}\right.$ body weight ${ }^{-1}$ ) warmed to body temperature was used in $20-\mathrm{mL}$ aliquots. The first aliquot of recovered BAL fluid was treated separately and 2-4 mL were used for microbiological investigations. The other samples were pooled, and, after filtration through gauze and centrifugation for $10 \mathrm{~min}$ at $200 \times \mathrm{g}$ to remove cells and debris, the supernatant was stored at $-70^{\circ} \mathrm{C}$. The cell-free supernatant was fractionated by differential centrifugation for $30 \mathrm{~min}$ at $40,000 \times g$ at $4{ }^{\circ} \mathrm{C}$ into a fraction that contained the SAs, which have less surface activity, and the more surface-active fraction containing LAs, which sediment to the bottom of the tube $[11,13]$.

\section{Phospholipid analysis}

As described previously [11], lipids were extracted from aliquots of the pooled samples and the phospholipid content determined from the inorganic phosphate content. This assay was adapted for use in microtitre plates. All measurements were performed in duplicate.

Solid-phase enzyme-linked immunosorbent assays for surfactant proteins $A$ and $B$

These assays were performed as described previously [14]. All samples were assessed in duplicate.

\section{Enzyme-linked immunosorbent assay for surfactant protein $C$}

The SP-C analysis was performed as previously described [15]. In brief, standard (human recombinant dipalmitoyl-SP-C; ALTANA Pharma AG, Constance, Germany), $20-\mu \mathrm{L}$ BAL fluid samples and a BAL fluid sample spiked with SP-C, as internal standard, were serially diluted in $80 \%$ 2-propanol in polystyrene microtitre plates (Polysorpß F96; Nunc, Wiesbaden, Germany). After drying for $6 \mathrm{~h}$ at $37^{\circ} \mathrm{C}$, $100 \mu \mathrm{L}$ trifluoroethanol was added and the plates dried again for $2 \mathrm{~h}$. The plates were then washed twice with $200 \mu \mathrm{L}$ methanol and three times with $200 \mu \mathrm{L}$ $50 \mathrm{mM}$ tris-(hydroxymethyl)-aminomethane (Tris)/ hydrochloric acid $(\mathrm{HCl})$ containing $0.5 \%$ Tween 20 (pH 7.6). Polyclonal rabbit anti-SP-C (1:10,000 in $50 \mathrm{mM}$ Tris- $\mathrm{HCl} / 1 \%$ bovine serum albumin (BSA); a gift from W. Steinhilber, ALTANA Pharma AG) was then added and the plates incubated for $12-15 \mathrm{~h}$ at room temperature. After washing three times, bound anti-SP-C was detected by a peroxidase-conjugated antirabbit antibody $(1: 1,000$ in $50 \mathrm{mM}$ Tris-HCl/1\% BSA, pH 7.6; Calbiochem, Bad Soden, Germany) and $20 \mathrm{mg}$ 2,2' -azino-di-3-ethyl-benzthiazolinesulphonate 
Table 1. - Children with malignancies ${ }^{\#}$

\begin{tabular}{|c|c|c|c|c|c|c|c|c|}
\hline Patient & Age yrs & Sex & Diagnosis & $\begin{array}{l}\text { Pathogens } \\
\text { in BAL fluid }\end{array}$ & $\begin{array}{c}\text { PBL } \\
\text { cells } \cdot \mu \mathrm{L}^{-1}\end{array}$ & $\begin{array}{c}\text { Infiltrates } \\
\text { on chest } \\
\text { radiography }\end{array}$ & $\begin{array}{c}\text { Steroids } \\
\text { in last } \\
2 \text { weeks }\end{array}$ & Outcome \\
\hline 1 & 5.3 & $\mathrm{~F}$ & ALL & None & 2600 & $\begin{array}{l}\text { Diffuse, } \\
\text { interstitial }\end{array}$ & Yes & Died \\
\hline 2 & 5.0 & $\mathrm{~F}$ & ALL & None & 800 & $\begin{array}{c}\text { Diffuse, } \\
\text { interstitial }\end{array}$ & Yes & Died \\
\hline 3 & 7.8 & $\mathrm{~F}$ & AML & None & 300 & $\begin{array}{l}\text { Focal, consolidated } \\
\text { right S4 }\end{array}$ & No & Unchanged \\
\hline 4 & 7.9 & $\mathrm{~F}$ & AML & Paecilomyces & 2000 & $\begin{array}{l}\text { Focal, consolidated } \\
\text { right S4 }\end{array}$ & No & Improved \\
\hline 5 & 3.2 & M & AML & None & 48100 & Diffuse, nodular & No & Died \\
\hline 6 & 2.0 & $\mathrm{~F}$ & AML & Aspergillus & 800 & $\begin{array}{l}\text { Focal, consolidated } \\
\text { right S4/S6 }\end{array}$ & No & Improved \\
\hline 7 & 2.2 & $\mathrm{~F}$ & AML & None & 2300 & $\begin{array}{l}\text { Focal, consolidated } \\
\text { right } S 4 / \mathrm{S} 6\end{array}$ & No & Improved \\
\hline 8 & 13.8 & M & $\begin{array}{l}\text { ALL, } 74 \text { days } \\
\text { after BMT }\end{array}$ & Aspergillus & 10000 & $\begin{array}{l}\text { Focal, consolidated } \\
\text { right } S 4 / \mathrm{S} 8\end{array}$ & No & Improved \\
\hline 9 & 13.9 & M & $\begin{array}{l}\text { ALL, } 133 \text { days } \\
\text { after BMT }\end{array}$ & None & 3600 & $\begin{array}{l}\text { Focal, consolidated } \\
\text { right S4/S8 }\end{array}$ & Yes & Died \\
\hline 10 & 6.3 & $\mathrm{~F}$ & $\begin{array}{l}\text { ALL, } 17 \text { days } \\
\text { after BMT }\end{array}$ & None & 62000 & Diffuse, interstitial & No & Died \\
\hline 11 & 14.2 & $\mathrm{~F}$ & $\begin{array}{l}\text { SAA, } 84 \text { days } \\
\text { after BMT }\end{array}$ & None & NA & Diffuse, nodular & No & Improved \\
\hline 12 & 15.6 & $\mathrm{~F}$ & ALL & $\begin{array}{l}\text { Pseudomonas } \\
\text { putida }\end{array}$ & 2200 & $\begin{array}{c}\text { Focal, consolidated } \\
\text { left S8 }\end{array}$ & Yes & Improved \\
\hline 13 & 16.5 & $\mathrm{M}$ & HD & Cytomegalovirus & 14000 & Diffuse, interstitial & No & Improved \\
\hline 14 & 16.0 & M & ALL & Aspergillus & 9000 & $\begin{array}{l}\text { Focal, consolidated } \\
\text { right S4 }\end{array}$ & No & Improved \\
\hline 15 & 4.2 & M & ALL & None & 4900 & $\begin{array}{l}\text { Focal, consolidated } \\
\text { lingula }\end{array}$ & No & Improved \\
\hline 16 & 7.6 & M & AML & $\begin{array}{c}\text { Staphylococcus } \\
\text { epidermidis }\end{array}$ & 600 & $\begin{array}{c}\text { Focal, consolidated } \\
\text { right S8 }\end{array}$ & No & Improved \\
\hline 17 & 11.1 & M & SAA & None & NA & $\begin{array}{c}\text { Focal, consolidated } \\
\text { lingula }\end{array}$ & Yes & Improved \\
\hline 18 & 13.0 & $\mathrm{~F}$ & ALL & None & 1100 & Diffuse, interstitial & Yes & Improved \\
\hline 19 & 7.0 & M & AML & Aspergillus & 3800 & Diffuse, interstitial & Yes & Died \\
\hline 20 & 9.0 & M & ALL & None & NA & $\begin{array}{c}\text { Focal, consolidated } \\
\text { left S1 }\end{array}$ & No & Improved \\
\hline 21 & 14.0 & M & AML & Aspergillus & 4000 & $\begin{array}{l}\text { Focal, consolidated } \\
\text { right S4 }\end{array}$ & No & Improved \\
\hline 22 & 8.2 & M & AML & None & 300 & Diffuse, interstitial & No & Died \\
\hline 23 & 14.5 & $\mathrm{~F}$ & NHL & Lactobacillus & 100 & $\begin{array}{c}\text { Focal, consolidated } \\
\text { right S9 }\end{array}$ & Yes & Improved \\
\hline 24 & 4.5 & M & RSA & None & 3600 & $\begin{array}{l}\text { Focal, consolidated } \\
\text { right lung }\end{array}$ & No & Died \\
\hline
\end{tabular}

BAL: bronchoalveolar lavage; PBL: peripheral blood leucocytes; F: female; ALL: acute lymphocytic leukaemia; AML: acute myeloid leukaemia; M: male; BMT: bone marrow transplantation; SAA: severe aplastic anaemia; NA: not available; HD: Hodgkin's disease; NHL: non-Hodgkin's lymphoma; RSA: rhabdomyosarcoma. \#: all presented with fever; `: of current episode.

(ABTS; Boehringer, Mannheim, Germany) in $30 \mathrm{~mL}$ substrate buffer. All samples were analysed in duplicate. The recovery of exogenous SP-C spikes (mean $99 \%$ ) was independent of the BAL fluid protein concentration. The enzyme-linked immunosorbent assay (ELISA) was not influenced by the total protein content of the samples; in particular, SP-A, SP-B and serum albumin did not interfere with SP-C measurement [15].

Enzyme-linked immunosorbent assay for surfactant protein $D$

Maxisorp 96-well plates (Nunc, Roskilde, Denmark) were coated overnight at $4{ }^{\circ} \mathrm{C}$ with a monoclonal mouse antirat SP-D (VI F 11; BMA, Augst, Switzerland) cross-reacting with human SP-D (a gift of E. Crouch, Dept of Pathology, Washington University, St Louis, MO, USA) at $2 \mu \mathrm{g} \cdot \mathrm{mL}^{-1}$ in carbonate buffer $\left(15 \mathrm{mM} \mathrm{Na} \mathrm{CO}_{3}, 35 \mathrm{mM} \mathrm{NaHCO}\right.$, $\mathrm{pH}$ 9.6). After blocking with $10 \mathrm{mg} \cdot \mathrm{mL}^{-1} \mathrm{BSA}$ in Trisbuffered saline containing $5 \mathrm{mM} \mathrm{CaCl} 2$, samples or standard were incubated for $1 \mathrm{~h}$ at $37^{\circ} \mathrm{C}$. Bound SP-D was detected with the monoclonal mouse antirat SP-D antibody (II E 11-biotin; BMA) in blocking buffer, followed by $1 \mathrm{~h}$ incubation at $37^{\circ} \mathrm{C}$ with avidin-biotinhorseradish peroxidase complex (ABComplex; Dako, Glostrup, Denmark), diluted 1:100 in blocking buffer. The lower limit of detection was $30 \mathrm{ng}$ human 
$\mathrm{SP}-\mathrm{D} \cdot \mathrm{mL}^{-1}$. ABTS and hydrogen peroxide were used at room temperature for the colorimetric reaction and the products determined spectrophotometrically at $405 \mathrm{~nm}$.

\section{Pseudomonas aeruginosa binding assays for surfactant proteins $A$ and $D$}

The Nunc Maxisorp microtitre plates were coated overnight at $4{ }^{\circ} \mathrm{C}$ with Pseudomonas aeruginosa $\mathrm{P} 11$, a nonmucoid clinical isolate from a patient with cystic fibrosis, in carbonate buffer. After blocking and washing as described for the ELISAs, standards or $100 \mu \mathrm{L}$ samples at $160 \mathrm{ng} \cdot \mathrm{mL}^{-1}$ for SP-D and $50 \mathrm{ng} \cdot \mathrm{mL}^{-1}$ for SP-A were added in the presence of $2 \mathrm{mM} \mathrm{CaCl}_{2}$. In cases where the concentration was $<160$ or $<50 \mathrm{ng} \cdot \mathrm{mL}^{-1}$, respectively, samples were not prediluted. All samples were then diluted in the plates in four steps in order to target the optimal concentration range of the binding assay and incubated for $3 \mathrm{~h}$ at $25^{\circ} \mathrm{C}$. After washing, cross-linking with glutaraldehyde for $15 \mathrm{~min}$ and blocking, detection and visualisation of bound SP-A and SP-D was carried out as described for the SP-A or SP-D ELISA. All assays were performed in duplicate. The amount of the respective collectin (SP-A or SP-D) detected in a control sample was divided by the amount of standard bound at that collectin concentration. The median value was determined and the carbohydratebinding capacity of each sample expressed as a percentage of this value.

\section{Surface tension}

The surface tension-modifying properties of the LA fraction were evaluated using a pulsating bubble surfactometer (Electronetics, Amherst, NY, USA) as described previously [14]. Adsorption was defined as the surface tension obtained $10 \mathrm{~s}$ after formation of the bubble and minimum surface tension as the surface tension after $5 \mathrm{~min}$ of pulsations $\left(20\right.$ cycles $\cdot \mathrm{min}^{-1}$; minimum radius $0.40 \mathrm{~mm}$ and maximum radius $0.55 \mathrm{~mm}$ ), determined at the minimum radius of the bubble.

\section{Statistical analysis}

Data are given as median with interquartile range and range for $\mathrm{n}$ independent determinations. The results of the surfactant protein determinations are expressed relative to the volume of BAL fluid recovered, as recommended by the European Respiratory Society Task Force on BAL [16]. However, in order to permit comparisons with other studies, the results are also expressed relative to protein and phospholipid concentration. Spearman rank correlation coefficients were calculated to determine correlation between the different variables. Comparisons were made by Kruskal-Wallis analysis of variance to calculate an overall p-value for the comparison of the four groups, i.e. the controls, all children with malignancies, and those with and without pathogens in BAL fluid. The multiple comparisons among the various groups were made by Dunn's post hoc test. A p-value of $<0.05$ was considered significant; all p-values given are exact [17].

\section{Results}

The primary goal of the present study was to compare the whole group of children with malignancy, fever and chest infiltrates with the control children. In addition, the first group was divided into those with ( $\mathrm{n}=10$, age 13.9 yrs (range 2.0-16.5 yrs)) and without ( $\mathrm{n}=14$, age 7.1 yrs (range 2.2-14.2 yrs)) pathogens recovered from their BAL fluid. The volume of BAL fluid recovered was lower in children with pathogens in their lavage fluid (table 2). The total cell count was increased in the presence of pulmonary infiltrates, irrespective of the presence or absence of pathogens. The percentage of neutrophils was increased from 4 to $>10$-fold at the expense of alveolar macrophages, with only a marginal increase in the proportion of lymphocytes (table 2).

In children with malignancies, fever and chest infiltrates, total BAL fluid protein was increased approximately four-fold, whereas total phospholipids remained unchanged (table 3). SP-A levels were increased approximately four-fold, and a more pronounced increase (almost 10-fold) was seen in those children with pathogens recovered from their BAL fluid (table 3). SP-A levels remained increased even when corrected for BAL fluid recovery $\left(246 \mathrm{ng} \cdot \mathrm{mL}^{-1}\right.$ (range $51-1,109 \mathrm{ng} \cdot \mathrm{mL}^{-1}$ ) in healthy children versus $794 \mathrm{ng} \cdot \mathrm{mL}^{-1}$ (range $\left.126-3,313 \mathrm{ng} \cdot \mathrm{mL}^{-1}\right)$ in children with malignancy, $\mathrm{p}=0.0004)$. The binding capacity of SP-A for P. aeruginosa was not different among all the groups tested (table 3 ). Neither SP-D concentration nor its binding capacity for $P$. aeruginosa was altered in the children with malignancies, fever and infiltrates (table 3).

Although the concentration of the hydrophobic SP-B did not differ between the groups, SP-C levels were clearly increased in children with malignancies, fever and infiltrates, irrespective of whether or not pathogens were recovered from BAL fluid (table 4). These children also had an increased SA fraction (table 4). Overall, the biophysical properties of the LA fraction, i.e. minimal surface tension at all time points up to $5 \mathrm{~min}$ and adsorption to an air/water surface, were not altered (table 4). No differences were found for SP-A, -B, -C and -D when the children with malignancy and fever were grouped according to the appearance of chest infiltrates, i.e. diffuse or interstitial (table 1).

\section{Discussion}

In children with malignancies, fever and chest infiltrates, levels of SP-A were increased, the increase being most pronounced in those patients with pathogens in their BAL fluid. The increase was 4-10-fold and did not reflect differences in BAL fluid recovery. This increase in SP-A level probably reflects regulatory phenomena, i.e. an acute-phase reaction of 
Table 2. - Recovery and cellular composition of bronchoalveolar lavage (BAL) fluid

Control children
Children with

malignancies, fever and chest infiltrates

$\begin{array}{lcc}\text { All patients } & \begin{array}{c}\text { No BAL } \\ \text { fluid pathogens }\end{array} & \begin{array}{c}\text { With BAL } \\ \text { fluid pathogens }\end{array}\end{array} \quad$-value ${ }^{\#}$

\begin{tabular}{|c|c|c|c|c|c|}
\hline Subjects $\mathrm{n}$ & 24 & 24 & 14 & 10 & \\
\hline Recovery \% & $\begin{array}{c}64.5(59.0-72.5 \\
45.0-94.0)\end{array}$ & $\begin{array}{c}60.0(55.5-72.5 \\
31.0-85.0)\end{array}$ & $\begin{array}{c}70.5(59.0-75.0 \\
54.0-85.0)\end{array}$ & $\begin{array}{c}55.5(40.0-62.5, \\
31.0-72.0)^{*}\end{array}$ & 0.0290 \\
\hline $\begin{array}{l}\text { Total cell count } \\
\text { cells } \cdot \mu \mathrm{L}^{-1}\end{array}$ & $\begin{array}{c}6.0(2.7-11.7 \\
0.5-45.9)\end{array}$ & $\begin{array}{c}22.1(11.6-76.2 \\
1.9-629.2)^{* * *}\end{array}$ & $\begin{array}{c}18.9(9.1-88.8 \\
1.9-629.2)^{* *}\end{array}$ & $\begin{array}{c}25.1(10.0-87.3, \\
4.7-493.7)^{*}\end{array}$ & 0.0001 \\
\hline Macrophages $\%$ & $\begin{array}{c}84.5(72.7-90.0 \\
47.0-95.7)\end{array}$ & $\begin{array}{c}45.5(22.0-68.5 \\
2.0-99.0)^{* * *}\end{array}$ & $\begin{array}{c}61.5(22.0-75.5 \\
2.0-99.0)^{* *}\end{array}$ & $\begin{array}{c}36.0(19.0-61.5 \\
12.0-80.0)^{* * *}\end{array}$ & $<0.0001$ \\
\hline Lymphocytes \% & $\begin{array}{c}15.0(9.5-25.9 \\
4.0-50.0)\end{array}$ & $\begin{array}{c}34.0(15.5-65.0 \\
1.2-98.0)\end{array}$ & $\begin{array}{c}34.0(11.0-65.5, \\
1.2-98.0)\end{array}$ & $\begin{array}{c}35.0(15.5-74.0, \\
6.0-87.0)\end{array}$ & 0.0249 \\
\hline Neutrophils \% & $\begin{array}{c}0.6(0.3-1.1 \\
0.1-2.5)\end{array}$ & $\begin{array}{c}3.0(0.7-13.5 \\
0.0-74.0)^{*}\end{array}$ & $\begin{array}{c}2.6(0.1-6.5, \\
0.0-32.0)\end{array}$ & $\begin{array}{c}8.0(1.1-25.5 \\
0.4-74.0)^{* *}\end{array}$ & 0.0031 \\
\hline Eosinophils \% & $\begin{array}{c}0.2(0.0-0.4, \\
0.0-1.6)\end{array}$ & $\begin{array}{c}0.2(0.0-0.6, \\
0.0-15.0)\end{array}$ & $\begin{array}{c}0.4(0.0-1.3, \\
0.0-8.0)\end{array}$ & $\begin{array}{c}0.1(0.0-0.7, \\
0.0-15.0)\end{array}$ & 0.8553 \\
\hline
\end{tabular}

Data are presented as median (interquartile range, range). ${ }^{\#}$ : differences between the four groups were calculated by KruskalWallis test; overall $\mathrm{p}$-values are given. *: $\mathrm{p}<0.05 ; * *: \mathrm{p}<0.01 ; * * *: \mathrm{p}<0.001$; versus control group (Dunn's post hoc test) for each.

the lungs to initiate local innate host defence mechanisms. In animal experiments, acute increases in SP-A concentration have been observed after intratracheal challenge with lipopolysaccharide or bacteria [18-20]. During pneumonia in immunoincompetent adult patients with acquired immune deficiency syndrome, increased levels of SP-A have been reported [21], whereas, in immunocompetent patients, SP-A levels were decreased $[8,9]$. In vitro SP-A gene expression is determined by multiple factors, including glucocorticoids, with differential responsiveness of the SP-A and SP-A $\mathrm{A}_{2}$ genes [22]. In animal experiments, SP-A

Table 3. - Total phospholipids (PLs), total protein and concentrations of the hydrophilic surfactant protein (SP) A and D

\begin{tabular}{|c|c|c|c|c|c|}
\hline & \multirow[t]{2}{*}{ Control children } & \multicolumn{3}{|c|}{$\begin{array}{l}\text { Children with malignancies, } \\
\text { fever and chest infiltrates }\end{array}$} & \multirow[b]{2}{*}{ p-value } \\
\hline & & All patients & $\begin{array}{l}\text { No BAL fluid } \\
\text { pathogens }\end{array}$ & $\begin{array}{l}\text { With BAL fluid } \\
\text { pathogens }\end{array}$ & \\
\hline $\begin{array}{l}\text { Phospholipid } \\
\mu \mathrm{g} \cdot \mathrm{mL}^{-1}\end{array}$ & $\begin{array}{l}8.3(4.5-12.3 \\
2.2-19.3) 21\end{array}$ & $\begin{array}{c}14.4(5.7-27.0 \\
0.4-125.1) 24\end{array}$ & $\begin{array}{c}15.7(4.8-32.2 \\
2.0-67.3) 14\end{array}$ & $\begin{array}{c}12.6(4.7-33.7 \\
0.4-125.1) 10\end{array}$ & 0.1509 \\
\hline Protein $\mu \mathrm{g} \cdot \mathrm{mL}^{-1}$ & $\begin{array}{l}31.2(24.0-47.0 \\
9.8-94.2) 24\end{array}$ & $\begin{array}{l}113.7(53.3-482.8 \\
3.2-1859.9) 24^{* * *}\end{array}$ & $\begin{array}{l}121.2(53.3-722.6 \\
25.8-1859.9) 14^{* * *}\end{array}$ & $\begin{array}{l}111.8(30.1-261.2 \\
18.2-557.6) 10\end{array}$ & 0.0001 \\
\hline $\begin{array}{l}\mathrm{SP}-\mathrm{A} \\
\mathrm{ng} \cdot \mathrm{mL}^{-1}\end{array}$ & $120.0(48.9-262.8$, & $479.1(215.7-1052.1$, & 368.8 (157.7-770.4, & $1218.5(274.3-2274.0$, & $<0.0001$ \\
\hline $\mathrm{ng} \cdot \mu \mathrm{g}$ protein $^{-1}$ & $\begin{array}{c}3.9(1.6-12.1 \\
0.8-26.4) 19\end{array}$ & $\begin{array}{c}54.2-3(J 5.2) 24 \\
6.3(0.7-12.2 \\
0.0-37.8) 24\end{array}$ & $\begin{array}{l}542-9 / 6.0) 14 \\
3.1(0.3-8.8 \\
0.0-37.8) 14\end{array}$ & $\begin{array}{c}107.4-3155.2) 10^{*} \\
8.8(4.6-23.1 \\
0.8-32.6) 10\end{array}$ & 0.1341 \\
\hline $\mathrm{ng} \cdot \mu \mathrm{g} \mathrm{PL}^{-1}$ & $\begin{array}{c}17.6(9.4-34.1 \\
4.6-81.5) 18\end{array}$ & $\begin{array}{c}40.6(17.2-106.7 \\
0.8-291.8) 24\end{array}$ & $\begin{array}{c}37.6(14.3-55.1 \\
0.8-97.7) 14\end{array}$ & $\begin{array}{c}122.0(17.5-227.1 \\
13.2-292.8) 10^{*}\end{array}$ & 0.0198 \\
\hline $\begin{array}{l}\text { SP-A binding to } \\
\mathrm{Pa} \% \text { control } \\
\text { SP-D }\end{array}$ & $\begin{array}{c}100.0(72.8-298.8 \\
6.2-629.3) 17\end{array}$ & $\begin{array}{l}70.1(25.5-199.2 \\
12.7-1970.1) 20\end{array}$ & $\begin{array}{c}150.7(45.6-276.3 \\
24.1-1970.1) 12\end{array}$ & $\begin{array}{l}25.0(16.5-75.6 \\
12.7-232.5) 8\end{array}$ & 0.0854 \\
\hline $\mathrm{ng} \cdot \mathrm{mL}^{-1}$ & $\begin{array}{c}37.7(14.0-66.3 \\
0.0-119.3) 24\end{array}$ & $\begin{array}{c}50.8(16.9-73.2 \\
0.0-208.8) 22\end{array}$ & $\begin{array}{c}40.3(21.0-60.4 \\
0.0-208.8) 12\end{array}$ & $\begin{array}{l}50.8(6.6-92.0 \\
0.0-105.0) 10\end{array}$ & 0.9961 \\
\hline $\mathrm{ng} \cdot \mu \mathrm{g}$ protein $^{-1}$ & $\begin{array}{l}1.1(0.4-2.3 \\
0.1-8.5) 23\end{array}$ & $\begin{array}{l}0.4(0.2-0.8 \\
0.0-2.7) 18^{*}\end{array}$ & $\begin{array}{c}0.6(0.1-0.9 \\
0.0-1.1) 10\end{array}$ & $\begin{array}{c}0.4(0.2-0.6 \\
0.2-2.71) 8\end{array}$ & 0.0304 \\
\hline $\mathrm{ng} \cdot \mu \mathrm{g} \mathrm{PL}^{-1}$ & $\begin{array}{l}3.4(1.8-12.0 \\
0.2-25.4) 20\end{array}$ & $\begin{array}{l}4.9(1.0-14.6 \\
0.1-124.3) 18\end{array}$ & $\begin{array}{l}1.5(0.9-33.1 \\
0.8-106.0) 10\end{array}$ & $\begin{array}{c}9.0(2.2-13.3 \\
0.1-124.3) 8\end{array}$ & 0.8478 \\
\hline $\begin{array}{l}\text { SP-D binding to } \\
\mathrm{Pa} \% \text { control }\end{array}$ & $\begin{array}{c}100.0(69.9-162.0 \\
52.3-265.2) 14\end{array}$ & $\begin{array}{c}344.7(39.6-444.9 \\
0.0-990.1) 14\end{array}$ & $\begin{array}{c}345.8(68.6-564.9 \\
0.0-741.7) 7\end{array}$ & $\begin{array}{c}343.7(140.5-729.9 \\
18.8-990.1) 7\end{array}$ & 0.2374 \\
\hline
\end{tabular}

Data are presented as median (interquartile range, range) $\mathrm{n} .{ }^{*}$ : differences between the four groups were calculated by Kruskal-Wallis test; overall p-values are given. BAL: bronchoalveolar lavage. Collectin binding to Pseudomonas aeruginosa $(\mathrm{Pa})$ is expressed relative to median binding in control lavages. ${ }^{*}: \mathrm{p}<0.05 ; * *: \mathrm{p}<0.01 ; * * * \mathrm{p}<0.001$; versus control group (Dunn's post hoc test) for each. 
Table 4. - Concentrations of large (LA) and small (SA) surfactant aggregate forms and the hydrophobic surfactant protein (SP) B and C and surface activity

\begin{tabular}{|c|c|c|c|c|c|}
\hline & \multirow[t]{2}{*}{ Control children } & \multicolumn{3}{|c|}{$\begin{array}{l}\text { Children with malignancies, } \\
\text { fever and chest infiltrates }\end{array}$} & \multirow[b]{2}{*}{ p-value ${ }^{\#}$} \\
\hline & & All patients & $\begin{array}{l}\text { No BAL } \\
\text { fluid } \\
\text { pathogens }\end{array}$ & $\begin{array}{l}\text { With BAL } \\
\text { fluid } \\
\text { pathogens }\end{array}$ & \\
\hline $\begin{array}{l}\mathrm{SA} \mu \mathrm{g} \\
\quad \text { protein } \cdot \mathrm{mL}^{-1}\end{array}$ & $\begin{array}{c}1.8(1.4-11.8 \\
0.8-31.3) 19\end{array}$ & $\begin{array}{l}10.0(4.7-16.4 \\
2.1-27.0) 10^{* *}\end{array}$ & $\begin{array}{l}13.4(5.0-22.1 \\
4.2-27.0) 6^{* *}\end{array}$ & $6.9(-, 2.1-15.2) 4$ & 0.0177 \\
\hline $\begin{array}{l}\mathrm{LA} \mu \mathrm{g} \\
\text { protein } \cdot \mathrm{mL}^{-1}\end{array}$ & $\begin{array}{c}10.9(5.2-25.5 \\
2.6-48.3) 18\end{array}$ & $\begin{array}{l}18.8(11.3-38.2 \\
10.5-109.9) 10\end{array}$ & $\begin{array}{l}18.8(10.7-38.2 \\
10.5-40.3) 6\end{array}$ & $23.3(-, 11.5-109.9) 4$ & 0.0937 \\
\hline $\mathrm{SA} / \mathrm{LA}$ & $\begin{array}{c}0.3(0.1-0.6 \\
0.1-0.9) 18\end{array}$ & $\begin{array}{c}0.4(0.2-0.6 \\
0.1-1.1) 10\end{array}$ & $\begin{array}{c}0.5(0.4-0.9 \\
0.4-1.1) 6\end{array}$ & $0.2(-, 0.1-0.4) 4$ & 0.0613 \\
\hline $\begin{array}{l}\mathrm{SP}-\mathrm{B} \\
\mathrm{ng} \cdot \mathrm{mL}^{-1}\end{array}$ & 189.9 (147.9-209.3, & 194.0 (163.0-265.9, & $185.9(163.0-239.5$, & 214.3 (153.2-313.7, & 0.4686 \\
\hline $\mathrm{ng} \cdot \mu \mathrm{g} \operatorname{protein}^{-1}$ & $\begin{array}{c}40.8-418.4) 24 \\
5.8(3.4-6.9 \\
1.6-22.6) 24\end{array}$ & $\begin{array}{c}125.7-646.8) 24 \\
2.6(0.5-4.0 \\
0.1-8.8) 24 * *\end{array}$ & $\begin{array}{c}125.7-620.1) 14 \\
1.8(0.3-5.6 \\
0.1-8.8) 14^{* *}\end{array}$ & $\begin{array}{c}128.6-646.8) 10 \\
2.9(0.9-4.8 \\
0.6-8.1) 10\end{array}$ & 0.0021 \\
\hline $\mathrm{ng} \cdot \mu \mathrm{g} \mathrm{PL}{ }^{-1}$ & $\begin{array}{l}24.8(14.6-43.8 \\
9.6-64.1) 21\end{array}$ & $\begin{array}{l}17.1(8.3-34.7 \\
1.6-380.1) 24\end{array}$ & $\begin{array}{l}10.5(8.2-32.6 \\
2.7-91.3) 14\end{array}$ & $\begin{array}{c}26.7(7.3-42.8 \\
1.6-380.1) 10\end{array}$ & 0.3357 \\
\hline $\begin{array}{l}\mathrm{SP}-\mathrm{C} \\
\mathrm{ng} \cdot \mathrm{mL}^{-1}\end{array}$ & $\begin{array}{c}62.1(28.3-98.8, \\
2.5-200.2) 24\end{array}$ & $\begin{array}{l}164.0(119.1-319.8 \\
75.6-1954.6) 24 * * *\end{array}$ & $\begin{array}{l}164.0(119.1-402.3 \\
94.5-1954.6) 14 * * *\end{array}$ & $\begin{array}{c}164.7 \text { (97.1-346.7, } \\
75.6-472.9) 10^{* *}\end{array}$ & $<0.0001$ \\
\hline $\mathrm{ng} \cdot \mu \mathrm{g}$ protein $^{-1}$ & $\begin{array}{l}1.8(1.1-2.6 \\
0.2-4.4) 24\end{array}$ & $\begin{array}{l}1.2(0.8-3.1 \\
0.1-5.7) 24\end{array}$ & $\begin{array}{c}1.5(0.5-3.9 \\
0.1-5.7) 14\end{array}$ & $\begin{array}{l}1.8(1.3-3.1 \\
0.3-4.9) 10\end{array}$ & 0.9316 \\
\hline $\mathrm{ng} \cdot \mu \mathrm{g} \mathrm{PL}^{-1}$ & $\begin{array}{l}7.2(3.5-15.3 \\
0.7-52.3) 21\end{array}$ & $\begin{array}{l}15.2(5.8-27.0 \\
1.2-434.0) 24\end{array}$ & $\begin{array}{l}13.0(5.8-66.2 \\
2.4-390.9) 14\end{array}$ & $\begin{array}{l}17.2(4.9-38.7 \\
1.2-434.0) 10\end{array}$ & 0.1530 \\
\hline rads $\mathrm{mN} \cdot \mathrm{m}^{-1}$ & $\begin{array}{l}45.5(29.8-49.7 \\
19.5-52.0) 9\end{array}$ & $\begin{array}{c}43.2(28.9-54.3 \\
22.6-69.2) 10\end{array}$ & $\begin{array}{c}43.0(28.9-53.0 \\
27.5-57.4) 6\end{array}$ & $\begin{array}{c}46.1(- \\
22.6-69.2) 4\end{array}$ & 0.9668 \\
\hline$\gamma \min \mathrm{mN} \cdot \mathrm{m}^{-1}$ & $\begin{array}{l}19.1(16.6-19.9 \\
13.8-21.8) 9\end{array}$ & $\begin{array}{l}18.7(14.4-20.7 \\
10.7-32.9) 10\end{array}$ & $\begin{array}{l}18.9(14.0-20.7 \\
10.7-20.7) 6\end{array}$ & $\begin{array}{c}18.0(- \\
11.5-32.9) 4\end{array}$ & 0.9937 \\
\hline
\end{tabular}

Data are presented as median (interquartile range, range) n. BAL: bronchoalveolar lavage; PL: phospholipid; $\gamma$ ads: surface tension after adsorption; $\gamma$ min: minimal surface tension in equilibrium after 100 pulsations. ${ }^{\#}$ : differences between the four groups were calculated by Kruskal-Wallis test; overall $\mathrm{p}$-values are given. *: $\mathrm{p}<0.05 ;{ }^{* *}: \mathrm{p}<0.01 ;{ }^{* *}: \mathrm{p}<0.001 ;$ versus control group (Dunn's post hoc test) for each.

messenger ribonucleic acid (mRNA) is upregulated by subcutaneous corticosteroids [23, 24]. In the present study, no differences in SP-A level were observed between those patients treated with and without corticosteroids, suggesting that recent therapeutic use of systemic steroids was not a principal factor determining BAL fluid SP-A concentration.

The binding capacity of SP-A for $P$. aeruginosa did not differ among the various groups tested. Binding to carbohydrate surfaces is a central characteristic of the collectins, and, as such, intimately associated with their ability to activate macrophages or remove microorganisms [2]. These results showed no gross impairment of the functional activity of SP-A. From the present data, there is no evidence for reduced concentrations of SP-A, as might have been associated with impaired removal of microorganisms from the lungs, and predicted from data from SP-A knockout mice $[4,25]$. Conversely, the results from the present group of patients suggest upregulation of SP-A with bacterial lung infection. Whether additional substitution of SP-A to reinforce the local pulmonary host defences may be worthwhile, i.e. by inhalation of human recombinant protein, needs to be tested in suitable animal models.

Based on a large body of in vitro data, SP-D is the other lung collectin which may very probably be involved in host defence [2]. However, the present results showed that neither its concentration nor its functional binding activity was changed. Thus, the possibility is excluded that reduced levels of SP-D might have been permissive for pulmonary infections. However, a potential failure to upregulate SP-D can only be assessed in longitudinal investigations with different control groups. No correlations were observed in the patients between the amount of SP-D in BAL fluid and the number of neutrophils (correlation coefficient $=-0.22, \mathrm{p}=0.33$ ), as reported for SP-D knockout mice [5]. Inhalation of lipopolysaccharide by rats also changed SP-D concentrations in BAL fluid, however, in this model system, the carbohydrate-binding sites of SP-D were occupied by lipopolysaccharide during the first $2 \mathrm{~h}$ after inhalation [26]. Summarising the data regarding the immunomodulatory aspects of the two collectins, differential regulation of SP-A and SP-D was found in children with malignancies, fever and chest infiltrates. SP-A concentrations were increased, particularly in children with pathogens in their BAL fluid, whereas SP-D levels were unchanged.

Surprisingly, the other major function of surfactant, its biophysical surface activity, was not altered in the 
present group of sick children in comparison to controls. However, the increase in SA levels indicated significant overall alterations of the surfactant system. The conserved surface activity can be explained by several mechanisms that may act alone or in combination. These include the observed increase in SP-A concentration, which would contribute to increased resistance of surfactant to inactivation by proteins leaking into the airspace [27]. In patients, the increase in total protein was approximately four-fold compared to the six-fold increase seen in patients with severe pneumonia [9], although no detailed clinical data were available for those patients. More importantly, SP-C levels were also consistently increased and may well contribute to the stabilisation of the surface activity of the surfactant, as suggested by animal and in vitro experiments [22]. Factors that regulate SP-C expression or concentration in the adult lung include tumour necrosis factor (TNF)- $\alpha$, corticosteroids and exposure to increased concentrations of inspired oxygen [28]. Although increased TNF- $\alpha$ concentration reduces SP-C gene transcription [29], increased levels of SP-C were observed and this cytokine was not assessed in the patients. The sick children in the present study were not exposed to significant oxygen therapy, but eight of them had received systemic steroids within the week prior to BAL. SP-C levels were not significantly different between those children treated or not treated with corticoids. There were also no correlations between SP-C and SP-A level or SP-B and SP-D level in the children, in accordance with animal experiments that suggest regulation of SP-C mRNA independent of that of the other surfactant proteins [28]. Unfortunately, no other quantitative data on SP-C levels in BAL fluid are available in humans for further comparisons.

In conclusion, children with malignancies and immunosuppression during therapy, who develop pulmonary complications with fever and infiltrates, have increased levels of both surfactant proteins $\mathrm{A}$ and $\mathrm{C}$ in their bronchoalveolar lavage fluid. The biophysical properties of the surfactant isolated were not impaired, although an increased fraction of small surfactant aggregates suggested some alterations in the alveolar metabolism of surfactant. The increased concentrations of surfactant proteins $\mathrm{A}$ and $\mathrm{C}$ might have conserved surfactant function. The greatest increase in surfactant protein A concentration was noted in those children with microorganisms recovered from their bronchoalveolar lavage fluid, consistent with the concept of an upregulated local pulmonary host defence system under the conditions described.
AG, Constance, Germany) for the polyclonal rabbit antihuman surfactant protein $\mathrm{C}$ antibody. The present article contains parts of the medical thesis of M. Neumann.

\section{References}

1. Lanino E, Sacco O, Kotitsa Z, et al. Fiberoptic bronchoscopy and bronchoalveolar lavage for the evaluation of pulmonary infiltrates after BMT in children. Bone Marrow Transplant 1996; 18: Suppl. 2, 117-120.

2. Crouch E. Collectins and pulmonary host defense. Am J Respir Cell Mol Biol 1998; 19: 177-210.

3. LeVine AM, Gwozdz J, Stark J, Bruno M, Whitsett JA, Korfhagen T. Surfactant protein-A enhances respiratory syncytial virus clearance in vivo. $J$ Clin Invest 1999; 103: 1015-1021.

4. LeVine AM, Kurak K, Bruno MD, Stark J, Whitsett JA, Korfhagen TR. Surfactant protein-A-deficient mice are susceptible to Pseudomonas aeruginosa infection. Am J Respir Cell Mol Biol 1998; 19: 700-708.

5. LeVine AM, Gwozdz J, Fisher J, Whitsett JA, Korfhagen T. Surfactant protein D modulates lung inflammation with respiratory syncytial virus infection in vivo. Am J Respir Crit Care Med 2000; 161: A515.

6. Greene K, Whitsett JA, Korfhagen T, Fisher J. SP-D expression regulates endotoxin mediated lung inflammation in vivo. Am J Respir Crit Care Med 2000; 161: A515.

7. Johansson J, Curstedt T. Molecular structures and interactions of pulmonary surfactant components. Eur J Biochem 1997; 244: 675-693.

8. Baughman RP, Sternberg RI, Hull W, Buchsbaum JA, Whitsett JA. Decreased surfactant protein A in patients with bacterial pneumonia. Am Rev Respir Dis 1993; 147: 653-657.

9. Günther A, Siebert C, Schmidt R, et al. Surfactant alterations in severe pneumonia, acute respiratory distress syndrome, and cardiogenic lung edema. Am J Respir Crit Care Med 1996; 153: 176-184.

10. Griese M. Pulmonary surfactant in health and lung diseases: state of the art. Eur Respir J 1999; 13: 14551476.

11. Griese M, Dietrich P, Potz C, Westerburg B, Bals R, Reinhardt D. Surfactant subfractions during nosocomial infection in ventilated preterm human neonates. Am J Respir Crit Care Med 1996; 153: 398-403.

12. Veldhuizen RA, Ito Y, Marcou J, Yao LJ, McGaig L, Lewis JF. Effects of lung injury on pulmonary surfactant aggregate conversion in vivo and in vitro. Am J Physiol 1997; 272: L872-L878.

13. Veldhuizen RA, Inchley K, Hearn SA, Lewis JF, Possmayer JF. Degradation of surfactant-associated protein B (SP-B) during in vitro conversion of large to small surfactant aggregates. Biochem J 1993;295: 141-147.

Acknowledgements. The excellent technical support of A. Schams is appreciated. The authors thank Y. Kuroki and International Reagents Corporation, Kobe, Japan, for the generous gift of the monoclonal mouse antihuman surfactant protein A antibody PC-6, E. Crouch (Dept of Pathology, Washington University, St Louis, MO, USA) for the recombinant human surfactant protein D and W. Steinhilber (ALTANA Pharma
14. Griese M, Birrer P, Demirsoy A. Pulmonary surfactant in cystic fibrosis. Eur Respir J 1997; 10: 1983-1988.

15. Schmidt R, Steinhilber W, Ruppert C, et al. An ELISA technique for quantification of surfactant apoprotein (SP)-C in bronchoalveolar lavage fluid. Am J Respir Crit Care Med 2002; 165: 470-474.

16. Haslam PL, Baughman R. Guidelines for measurement of acellular components and recommendations 
for standardization of bronchoalveolar lavage (BAL).

Eur Respir Rev 1999; 9: 25-157.

17. Motulsky H. Intuitive Biostatistics. New York, Oxford University Press, 1995.

18. van Helden H, Kuijpers WC, Steenvoorden D, et al. Intratracheal aerosolization of endotoxin (LPS) in the rat: a comprehensive animal model to study adult (acute) respiratory distress syndrome. Exp Lung Res 1997; 23: 297-316.

19. McIntosh J, Swyers AH, Fisher JH, Wright JR. Surfactant proteins A and D increase in response to intratracheal lipopolysaccharide. Am J Respir Crit Care Med 1996; 15: 509-519.

20. Sugahara K, Iyama K, Sano K, Kuroki Y, Akino T, Matsumoto M. Overexpression of surfactant protein SP-A, SP-B, and SP-C mRNA in rat lungs with lipopolysaccharide-induced injury. Lab Invest 1996; 74: 209-220.

21. Phelps DS, Rose RM. Increased recovery of surfactant protein A in AIDS related pneumonia. Am Rev Respir Dis 1991; 143: 1072-1075.

22. Rooney SA, Young SL, Mendelson CR. Molecular and cellular processing of lung surfactant. FASEB $J$ 1994; 8: 957-967.

23. Young SL, Ho Y-S, Silbajoris RA. Surfactant apoprotein in adult rat lung compartments is increased by dexamethasone. Am J Physiol 1991; 260: L161-L167.

24. Fisher JH, McCormack F, Park SS, Stelzner T, Shannon JM, Hofmann T. In vivo regulation of surfactant proteins by glucocorticoids. Am J Respir Cell Mol Biol 1991; 5: 63-70.

25. LeVine AM, Bruno MD, Huelsman KM, Ross GF, Whitsett JA, Korfhagen TR. Surfactant protein A-deficient mice are susceptible to group B streptococcal infection. J Immunol 1997; 158: 4336-4340.

26. van Rozendaal BA, van de Lest CH, van Eijk M, et al. Aerosolized endotoxin is immediately bound by pulmonary surfactant protein $\mathrm{D}$ in vivo. Biochim Biophys Acta 1999; 1454: 261-269.

27. Yukitake K, Brown C, Schlueter M, Clements J, Hawgood S. Surfactant apoprotein A modifies the inhibitory effect of plasma proteins on surfactant activity in vitro. Pediatr Res 1995; 37: 21-25.

28. Beers MF, Fisher AB. Surfactant protein C: a review of its unique properties and metabolism. Am J Physiol 1992; 263: L151-L160.

29. Bachurski C, Pryhuber G, Glasser SW, Kelly S, Whitsett JA. Tumor necrosis factor- $\alpha$ inhibits surfactant protein C. J Biol Chem 1995; 270: 19402-19407. 